\title{
Preparaion Of Lead Free Nanosized Barium Titanate And Barium Calcium Titanate- Zirconate Powders By Using Urea Formaldehyde Resin
}

\author{
Anwar S. Askar ${ }^{1}$, Doreya M. Ibrahim², , Doaa A. Abdel Aziz ${ }^{2}$, Mobarak H. Ali ${ }^{3}$ and Ezzat A. El- \\ Fadaly ${ }^{4}$.
}

${ }^{1}$ Research Institute Environmental Studies - El-Sadat City University

${ }^{2}$ National Research Centre, Dokki, Giza, Egypt.

${ }^{3}$ Environmental Studies and Research Institute, El-Sadat City University

\begin{abstract}
:
Barium titanate, $\mathrm{BaTiO}_{3}[\mathrm{BT}]$ and Barium calcium titanate-zirconate $\mathrm{BaCa}(\mathrm{Ti} \mathrm{Zr}) \mathrm{O}_{3}$ [BCTZ] powders were prepared utilizing sol gel polymeric method using urea formaldehyde resin, as a template. The obtained gel dried at $80^{\circ} \mathrm{C} / 48 \mathrm{~h}$, then calcined at different temperature 800,1000 and $1100^{\circ} \mathrm{C} / 3 \mathrm{~h}$. FT-IR analysis, thermal analysis in terms of DTA-TG were carried to the polymer gel, and gel hosting cations at $80^{\circ} \mathrm{C}$. Phase composition using X-ray diffraction (XRD) was investigated to the calcined powder at the previous temperatures, Microstructure using scanning electron microscopy (SEM) was studied at $1100^{\circ} \mathrm{C} / 3 \mathrm{~h}$. It was found that the pure perovskite of (Tetragonalorthorhombic-monoclinic) barium titanate $[\mathrm{BT}]$ and (Tetragonal-orthorhombicmonoclinic) [BCTZ] powder was obtained at a calcination condition of $1100{ }^{\circ} \mathrm{C}$ for 3h. The average crystal size $24.14 \mathrm{~nm}$ for BT powder while BCTZ powder recorded $22.83 \mathrm{~nm}$. Uniform grain microstructure powders contain nearly spherical pores was obtained
\end{abstract}

Key worde: Nanosized, Barium titanate $\left(\mathrm{Ba} \mathrm{TiO}_{3}\right)$, sol gel, powder, urea formaldehyde, resin.

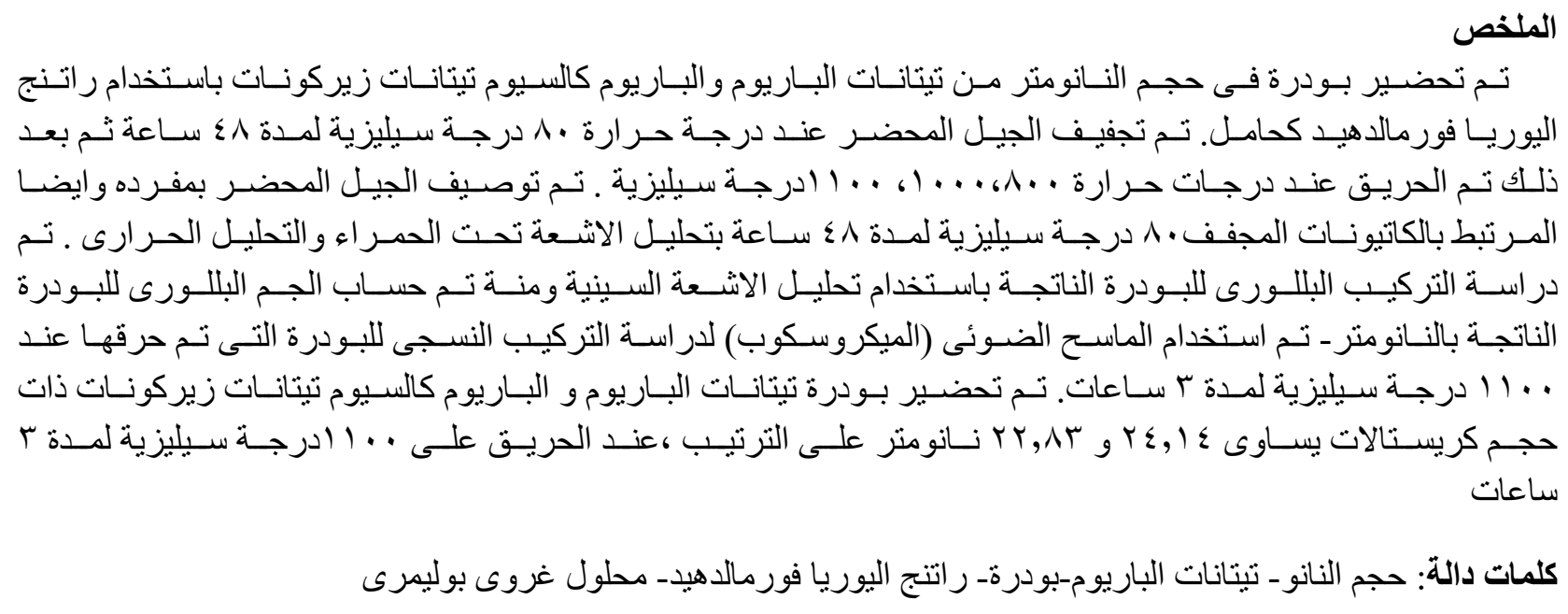




\section{INTRODUCTION}

Due to the high toxicity of lead based materials such as Lead titanate $\left(\mathrm{PbTiO}_{3}\right)$ that used in a wide range of electronic devices [Pontes et al., 2004]. The displacement of this compound by baium titanate compounds is an environmental goal. BT and BCTZ ceramics have a wide range of applications [Ertuğ, 2013], e.g. electronic, electro-optical, and electromechanical. Barium titanate, with a perovskite structure is a ferroelectric material with a common high dielectric constant widely utilized in the manufacturing of electronic components such as multilayer capacitors (MLCs), Positive temperature coefficient thermistors, piezoelectric transducers, and a variety of electro-optic devices. On the other hand, low dielectric constant barium titanate compounds which have been used in the microwave devices [Guo et al., 2012]. The most recently synthesis methods used for the preparation of BT powders; are solid- state reaction, mechano-chemical and wet chemical methods such as; co-precipitation, hydrothermal, sol-gel, as well as via polymeric precursor. BT can be synthesized as powder [Harizanov,1998; Cheung et al., 1999; Jiang et al., 2000; Beck et al., 2001 \& Lee and Zhang 2001].

The electrical properties of BT perovskite structure can be changed through the partial or complete substitution of barium and titanium sites by other cations, such as $\mathrm{Ca}^{2+}, \mathrm{Sr}^{2+}, \mathrm{Zr}^{4+}$ etc. [Herbert,1985 \& Yi and Kalkur, 2001].

Polymers are used as templates to guide the different inorganic species to homo-geneously distribute in a network to form nano particles after burning out the organic part, as described by Ibrahim et al., [1991, 1999], The auther prepared single oxide zirconium, (1991) as well as compounds namely, aluminum titanate (1999). The inorganic salts are added to the diluted solution of the prepared polymer or resin; namely urea formaldehyde. The conditions of preparation, $\mathrm{pH}$, temperature, and time of reaction are optimized for each reaction. Ethylene glycol was found to be the appropriate alcohol to terminate the reaction.

The aim of the present work to prepare BT as well as $\mathrm{Ba} 0.95-\mathrm{Ca} 0.05$ (Tio.85 - Zro.15) $\mathrm{O}_{3}$ (BCTZ) utilizing polymeric Sol-gel route; urea-formaldehyde resin innovated as a template.

\section{MATERIAL AND METHODS a-Starting Materials:}

The following chemical reagents were used for the preparation of BT as well as BCTZ powders via sol-gel polymeric route using urea-formaldehyde resin as a template, Barium chloride dihydrate, Calcium carbonate and Zirconium oxychloride were acquired from Oxfored, (India), titanium trichloride (Sigma, Aldrich), Formaldehyde (Loba Chemie Co., India), Ethylene glycol (Nice Chemicals Co., India), Urea (Sigma Chemicals Co.). Ammonia solution and Hydrochloric acid were bought from (Adwic Co.). The reactants were used as received from the suppliers without further purification except calcium chloride that prepared as the following:

One mole of Calcium carbonate reacts with two moles of Hydrochloric acid as the following equation:

$$
\mathrm{CaCO}_{3(\mathrm{~s})}+2 \mathrm{HCl}_{(\mathrm{aq})} \rightarrow \mathrm{CaCl}_{2}(\mathrm{aq})+\mathrm{CO}_{2}(\mathrm{~g})+\mathrm{H}_{2} \mathrm{O}_{(\mathrm{l})}
$$

The product, $\mathrm{CaCl}_{2}$ were dried in an oven at $80^{\circ} \mathrm{C}$ for $48 \mathrm{~h}$, then preserved from moisture to be used. 


\section{b- Procedure}

Resins were prepared using the proportion (1:2:2) of urea : formaldehyde : ethylene glycol. The reaction proceeded in two $\mathrm{pH}$ ranges. The starting $\mathrm{pH}$ was between $8-9$ and the reaction was terminated in a neutral media for resin free of cations. Also, $\mathrm{BaCl}_{2} .2 \mathrm{H}_{2} \mathrm{O}, \mathrm{TiCl}_{3}$ and $\mathrm{BaCl}_{2} .2 \mathrm{H}_{2} \mathrm{O}, \mathrm{CaCl}_{2}, \mathrm{TiCl}_{3}, \mathrm{ZrOCl}_{5} .8 \mathrm{H}_{2} \mathrm{O}$ were added in the stoichiometric ratio to get molar concentration of $\mathrm{Ba}^{2+}, \mathrm{Ti}^{4+}$ and $\left(\mathrm{Ba}^{2+}, \mathrm{Ca}^{2+}\right),\left(\mathrm{Ti}^{4+}, \mathrm{Zr}^{4+}\right) ;(1: 1)$ and $(0.95: 0.05)$, $(0.85: 0.15)$ as displayed in Table 1 . A batch to yield about $20 \mathrm{~g}$ of oxide powder was prepared for each composition. Resins hosting the respective cations, $\mathrm{Ba}^{2+}, \mathrm{Ti}^{4+}$ and $\left(\mathrm{Ba}^{2+}, \mathrm{Ca}^{2+}\right),\left(\mathrm{Ti}^{4+}\right.$, $\mathrm{Zr}^{4+}$ ) were synthesized by adding salt solutions of Barium, titanium chloride and Barium, calcium, titanium chloride beside zirconium oxychloride simultaneously with ethylene glycol in the final stage of reaction. The duration time of all step of the reaction including preparation of resin and resin hosting salts is three hours and the $\mathrm{pH}$ in the final stage were found to be in acidic media. The resin observed transparent clear in neutral media and transparent clear violet during hosting cations in acidic media. The different components and compounds prepared are shown in Table (1). Reagents were left to digest under reflux, while stirring for three hours comprising half an hour for the resin formation from urea and formaldehyde alone, while the other two hours and half after the addition of salt solution and alcohol. Water and other byproducts were pumped out using a vacuum pump. The resins were first slowly dried in an oven at $80^{\circ} \mathrm{C} / 48 \mathrm{~h}$. Then calcined to yield the respective ceramic oxide powders.

Table (1) Composition of resin hosting cations prepared by the polymeric sol-gel route using urea-formaldehyde resin.

\begin{tabular}{|c|l|l|c|}
\hline $\begin{array}{c}\text { Batch } \\
\text { name }\end{array}$ & $\begin{array}{l}\text { Resin } \\
\text { Concentration } \\
\text { (Urea:Formaldhyde } \\
\text { :Ethylene glycol) }\end{array}$ & $\begin{array}{l}\text { Total Mole of BaTiO } \\
\text { or } \mathbf{B a}_{\mathbf{0 . 9 5}}-\mathbf{C a}_{\mathbf{0 . 0 5}} \mathbf{T}_{\mathbf{3}} \\
-\mathbf{Z r}_{\mathbf{0 . 1 5}}\end{array}$ & $\begin{array}{c}\text { Concentration } \\
\text { of } \\
\text { Cation }\end{array}$ \\
\hline URBT & $1: 1: 2$ & 1 & $1.0: 0.0: 1.0:$ \\
& & & 0.0 \\
\hline URBCTZ & $1: 1: 2$ & 1 & $0.95: 0.05:$ \\
& & & $0.85: 0.15$ \\
\hline
\end{tabular}

The proportions of urea and formaldehyde were added in a three neck round bottom flask of a volume 500 C.C, Fig.1. The reagents comprised two thirds of the volume. A reflux condenser was inserted in the middle neck. A thermometer and a separating funnel were placed each on either side. The whole apparatus was immersed in a water bath heated up to the respective temperature.The prepared resin hosting salts were treated under vacuum distillation as well as aged overnight, dried for $48 \mathrm{~h}$ at $80^{\circ} \mathrm{C}$ and the blank experiment $\mathrm{BT}$ were calcined at different temperature $600,800,1000$ and $1100{ }^{\circ} \mathrm{C} / 3 \mathrm{~h}$. Thermal analysis in terms of (DTA/TG) was performed from 25 to $1000^{\circ} \mathrm{C}$ at a heating rate of $20^{\circ} \mathrm{C} / \mathrm{min}$ in (Netzsch STA $449 \mathrm{~F} 3$ Jupiter TG/DTAsystem, Selb, Germany) as well as Fourier-transform infra-red spectrum (FT-IR, Spectrum 400, PerkinElmer, USA) were carried to the dried gel of urea formaldehyde resin which dried at $80{ }^{\circ} \mathrm{C} / 48 \mathrm{~h}$ without cations, hosting two cations (BT) and hosting four cations (BCTZ). X-ray powder diffraction patterns of all samples obtained during the experiments were measured using a diffractometer with a $\mathrm{Cu}$ anode and a $\mathrm{Ni}$ filter for $\mathrm{CuK} \beta 1$ radiation, IK $\alpha 2: I K \alpha 1=2: 1$ (Philips PW1830, PanAnalytical, Almelo, the Netherlands). X-ray diffraction (XRD) used to examine phase composition. Microstructures were investigated to the selected 
samples by high-resolution scanning electron microscopy (HR-SEM, 0.5-2.0 keV, Zeiss 1550, Zeiss, Sliedrecht, Netherlands).

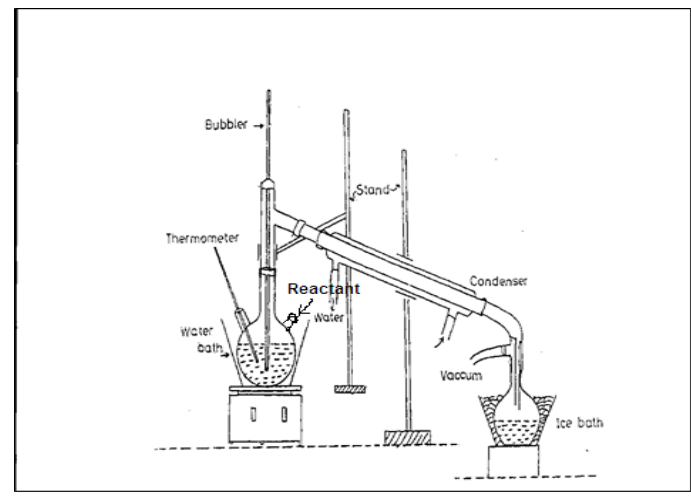

Fig.1. The apparatus used for the preparation of the precursor resins Urea formaldehyde.

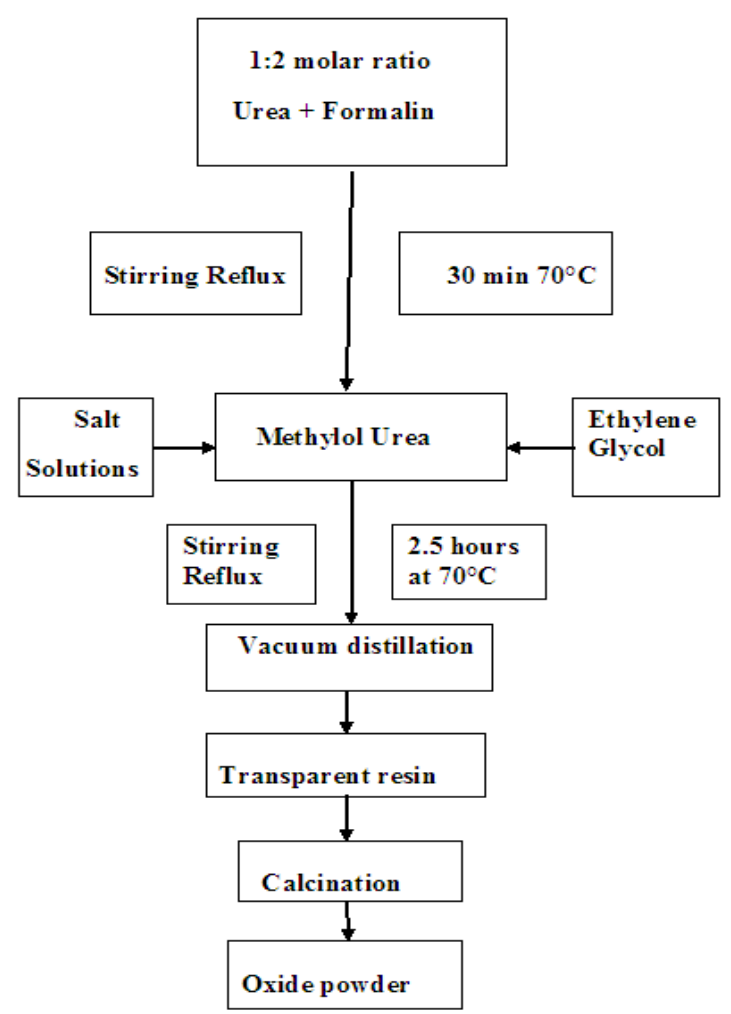

.2. The flow chart sol-gel polymeric route using urea formaldehyde.

\section{RESULTS AND DISCUSSION}

a- Characterization of dried gel and prepared powder 
The FTIR- spectral analysis of urea-formaldehyde modified with ethylene glycol is displayed in Fig. 3 and Table 2, The spectrum is clearly differentiated to show the vibration bands characteristic of $\mathrm{NH}$ and $\mathrm{OH}$ stretching at $3388 \mathrm{~cm}^{-1}, \mathrm{CH}$ stretching vibration represented by three bands occurring; at 3106.76, 2992.01 and $2772.17 \mathrm{~cm}^{-1}$. As well as $\mathrm{NH}_{2}$ in plane bending and $\mathrm{C}=\mathrm{O}$ stretching vibrations at $1621.84 \mathrm{~cm}^{-1}$. Sharp (C-O, CO-NH-R) stretching band taking place at $1400.06 \mathrm{~cm}^{-1}$ followed by two small bands at 1019.19 and $861.06 \mathrm{~cm}^{-1}$ corresponding to broad $\mathrm{NH}$ wagging vibration. The spectra of resins containing $\mathrm{Ba}^{2+}$ and $\mathrm{Ti}^{4+}$ cations are shown in Fig. 3. A broad band corresponding to the $\mathrm{NH}$ stretching, $\mathrm{OH}$ stretching and $\mathrm{CH}$ stretching occur between $3400-2400 \mathrm{~cm}^{-1}$. The splitting at 3121.22 and $3010 \mathrm{~cm}^{-1}$ refer to $(\mathrm{NH}, \mathrm{OH})$ and $\mathrm{CH}$ stretching bands, respectively. Another vibration band related to $\mathrm{CH}$ occurs at 2794.34 $\mathrm{cm}^{-1}$, the carbonyl band $\mathrm{C}=\mathrm{O}$ shows stretching bands at 1631.48 and $1539.8 \mathrm{~cm}^{-1}$. Metal coordinated to oxygen causes a shift in the position of this band. The sharp band at 1400 $\mathrm{cm}^{-1}$ is characteristic of mono-substituted amide to $\mathrm{C}-\mathrm{O}$ to give CO-NH-R. While small bands occurring at $1068.38 \mathrm{~cm}^{-1}$ are characteristic of $\mathrm{C}-\mathrm{O}$ and $\mathrm{CN}$

stretching vibration bands. Finally, absorption bands at wave numbers smaller than $800 \mathrm{~cm}^{-1}$ are related to M-O bands e.g., at 638.32 and $537.07 \mathrm{~cm}^{-1}$.

The spectrum of the resin hosting barium, calcium, titanium and zirconium cations is shown also in Fig. 3, it resembles to a great extent the latter ones. The vibration bands related to the different bands; mainly the $\mathrm{NH}$ stretching, $\mathrm{OH}$ and $\mathrm{CH}$ occur between 3400 to $2400 \mathrm{~cm}^{-1}$. The variation recorded is in the band at $1620.87 \mathrm{~cm}^{-1}$ corresponding to $\mathrm{C}=\mathrm{O}$. The same shift occurs in the position of the bands of metal CO-ordinated to oxygen. There is a sharp band at $1400 \mathrm{~cm}^{-1}$ corresponding to mono-substituted amide CO-NH-R. The band characteristic of C-O is still present at $1072 \mathrm{~cm}^{-1}$. Ba-O stretching mode, occurs at $1620.76 \mathrm{~cm}^{-1}$. N-H bending mode occurs at $855.27 \mathrm{~cm}^{-1}$. Absorption bands at wave numbers smaller than $800 \mathrm{~cm}^{-1}$ namely, bands occurring at 632.32 and $536.47 \mathrm{~cm}^{-1}$ are related to $\mathrm{M}-\mathrm{O}$ bonds.

The co-ordination of Metal with $\mathrm{O}^{2-}$ results in a shift of the bands in the region of 1600-1700 $\mathrm{cm}^{-1}$. The complexity of the spectrum indicates the complex chain structure present. The interaction of the different polymers with the hosted cations namely: $\mathrm{Ba}^{2+}$, or $\mathrm{Ba}^{2+} \mathrm{Ti}^{4+}$ and or $\mathrm{Ba}^{2+}, \mathrm{Ca}^{2+}-\mathrm{Ti}^{4+}$ and $\mathrm{Zr}^{4+}$ cations, show the absorption bands at wave numbers smaller than 800 $\mathrm{cm}^{-1}$ attributed to $\mathrm{M}-\mathrm{O}$ bonds, as given by Harizanov et al., (2004). The coordinated bonds of; $\mathrm{NH}$ out of plane, $\mathrm{C}=\mathrm{O}$ stretching vibration, $\mathrm{NH}$ bending and $\mathrm{CH}$ out of plane in the range 700 $1800 \mathrm{~cm}^{-1}$ caused a shift and splitting of the bands. The complexity of the spectrum indicates the complex chain structure present. Ba-O stretching mode reported by Bazeera and Amrin, (2017) and $\mathrm{C}=\mathrm{O}$ stretching vibration taking place at $1610.27 \mathrm{~cm}^{-1}$ evidence the substitution. Also, a new band appears at 564. $07 \mathrm{~cm}^{-1}$ corresponding to $\mathrm{Ba}-\mathrm{O}$ stretching mode as demonstrated by Akbarzadeh and Amiri, (2015). Whereas, chlorine did not participate in the structure of the resin as indicated by the absence of any specific FTIR-band in the region 230$380 \mathrm{~cm}^{-1}$. The resin hosting either two cations namely $\mathrm{Ba}^{2+}$ and $\mathrm{Ti}^{4+}$ or four cations $\mathrm{Ca}^{2+}$-and $\mathrm{Zr}^{4+}$ beside $\mathrm{Ba}^{2+}$ and $\mathrm{Ti}^{4+}$ cations show nearly the same spectra with slight difference. In the latter case, the band in $\mathrm{NH}$, the sharp bands presenting the $\mathrm{C}-\mathrm{O}$ and $\mathrm{C}=\mathrm{O}$ groups in the former $\left(\mathrm{Ba}^{2+}, \mathrm{Ti}^{4+}\right)$ broadens shifts and splitts with the introduction of the two other cations. The $\mathrm{NH}$ wagging, $\mathrm{CH}$ out of plane is shifted from 780.06 to $855.27 \mathrm{~cm}^{-1}$. The bands characteristic of M$\mathrm{O}$ bonding for all cation substitution occur between $800-400 \mathrm{~cm}^{-1}$. The substitution of $\mathrm{Ba}-\mathrm{O}$, $\mathrm{Ca}-\mathrm{O}$ show bands at higher wave length than $800 \mathrm{~cm}^{-1}$ indicating the chelation with $\mathrm{C}=\mathrm{O}$ stretching vibration occurs at 1631.48 and $1620.87 \mathrm{~cm}^{-1}$, respectively, as given by Bazeera and Amrin, (2017). Titanium chelation in the resin structure, as reported by Abd-EL-Mounem, 
(1997). caused a shift in the bands at 1400 and $1078 \mathrm{~cm}^{-1}$ presenting $\mathrm{C}=\mathrm{O}, \mathrm{CH}_{2}$ groups. While the bands related to Ti-O and $\mathrm{Zr}-\mathrm{O}$ occur at 1068.38 and $1400 \mathrm{~cm}^{-1}$. Chelation of Ti-O-Ti occurs at $780.06,855.27$ and $638.32632 .32 \mathrm{~cm}^{-1}$, respectively. while the bands related to Ti-O and $\mathrm{Zr}-$ $\mathrm{O}$ occur at1068.38 and $1400 \mathrm{~cm}^{-1}$. Chelation of Ti-O-Ti occurs at 780.06, 855.27 and 638.32 $632.32 \mathrm{~cm}^{-1}$, respectively.

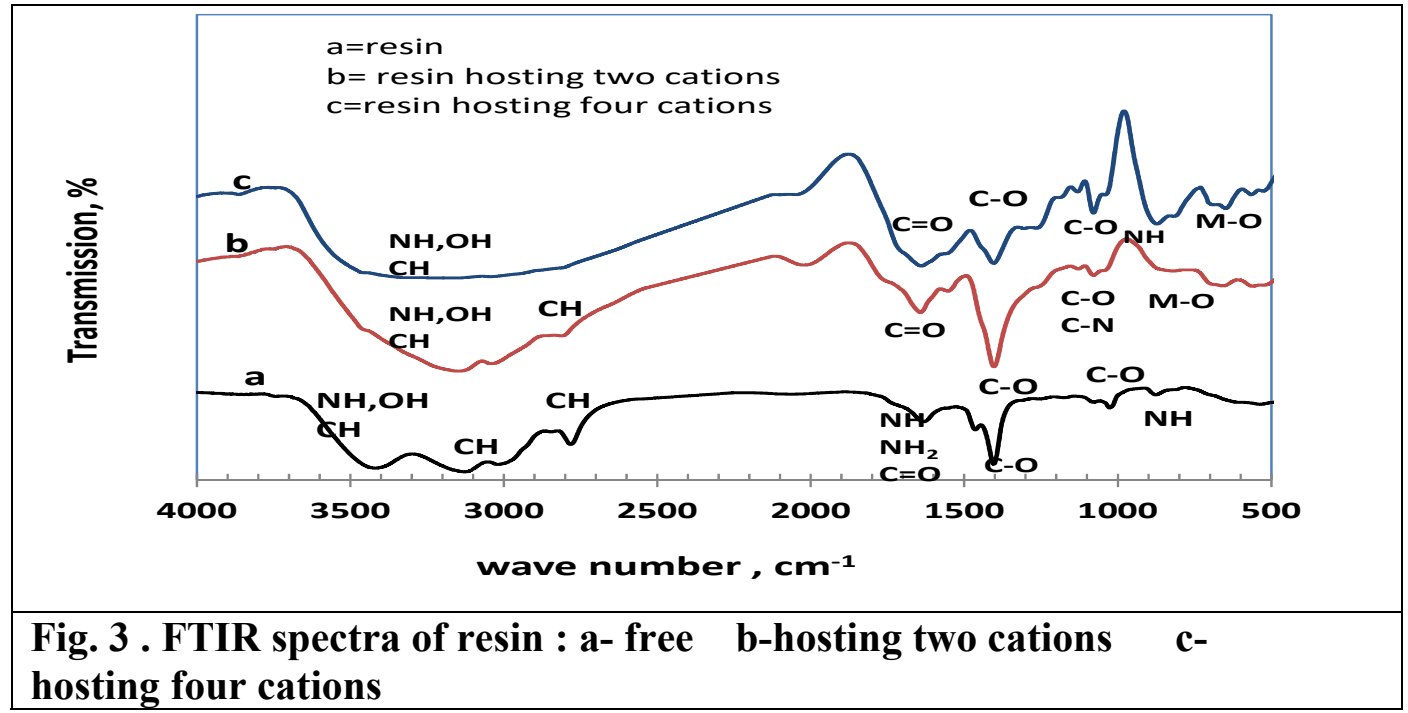

Table 2. FTIR spectra of resin free and hosting different number of cations

\begin{tabular}{|c|c|c|c|}
\hline Polymers & $\begin{array}{l}\text { Urea } \\
\text { formaldehyde } \\
\text { resin }\end{array}$ & $\begin{array}{l}\text { Urea formaldehyde } \\
\text { resin hosting } \\
\text { hosting } \mathrm{Ba}^{2+}, \mathrm{Ti}^{4+} \\
\text { cations }\end{array}$ & $\begin{array}{c}\text { Urea formaldehyde } \\
\text { resin hosting } \\
\mathrm{Ba}^{2+}, \mathrm{Ca}^{2+}, \mathrm{Ti}^{4+} \text { and } \\
\mathbf{Z r}^{4+} \text { cations }\end{array}$ \\
\hline $\begin{array}{l}\text { Types } \\
\text { of bands }\end{array}$ & $\begin{array}{c}\text { Wave number, } \\
\mathrm{cm}^{-1}\end{array}$ & Wave number, $\mathrm{cm}^{-1}$ & Wave number, $\mathrm{cm}^{-1}$ \\
\hline $\begin{array}{l}\text { NH stretching } \\
\text { vibration }\end{array}$ & 3388 & 3121.22 & $2780.84,3438.45$ \\
\hline $\begin{array}{l}\text { OH stretching } \\
\text { vibration }\end{array}$ & 3388 & 3121.22 & $2780.84,3438.45$ \\
\hline $\begin{array}{l}\mathrm{CH} \text { stretching } \\
\text { vibration }\end{array}$ & $\begin{array}{c}3106.76,2992.01 \\
2772.17\end{array}$ & 3010 & $2780.84,3438.45$ \\
\hline NH out of plane & 1621.84 & 1539.88 & 1535 \\
\hline $\mathrm{NH}_{2}$ in plane bend & 1621.84 & -- & -- \\
\hline $\begin{array}{l}\mathrm{C}=\mathrm{O} \text { stretching } \\
\text { vibration }\end{array}$ & 1621.84 & 1631.48 & 1620.8 \\
\hline $\begin{array}{l}\text { C-O (CO-NH-R) } \\
\text { stretching }\end{array}$ & $1400.06,1019.19$ & $1400,1068.38$ & 1400,1072 \\
\hline $\begin{array}{l}\mathrm{NH} \text { wagging, } \mathrm{CH} \\
\text { out of plane }\end{array}$ & 861.06 & 780.06 & 855.27 \\
\hline $\begin{array}{l}\text { C-N stretching } \\
\text { vibration }\end{array}$ & -- & 1068.38 & 855.27 \\
\hline
\end{tabular}




\begin{tabular}{|l|c|c|c|}
\hline N-H Bending mode & 861.06 & 780.06 & 855.27 \\
\hline Ba-O stretching mode & -- & $1631.48,1539.80,1068.38$, & $1620.87,1072$ \\
or M-O & & $638.32,537.07$ & $632.32,536.47$ \\
\hline
\end{tabular}

TGA of urea-formaldehyde resin modified with ethylene glycol is shown in Fig. 4 and Table (3) and DTA is show in Fig. 4 and Table (4). depicting a dissociation reaction of the organic resin occurring in three steps in the TGA curve evidenced by endothermic or exothermic peaks explain the effect of heat during these three main steps; The first step starts from 40 and ends at $220^{\circ} \mathrm{C}$, with a loss in weight equivalent to about $31.75 \%$, This is attributed to the loss of reaction by-products as ammonium chloride, indicative of dehydration of the precursor preceded at $75.06^{\circ} \mathrm{C}, 89.11{ }^{\circ} \mathrm{C}$ as well as melting of urea formaldehyde resin started at as indicated by small sholder at $171.66^{\circ} \mathrm{C}, 214.4^{\circ} \mathrm{C}$ showed by DTA curve.The second step takes place between 220 and $325^{\circ} \mathrm{C}$ with a loss in weight of $51.43 \%$, which corresponds to the combustion of the carbonaceous residue left of resin evidenced by small exothermic peaks at 235.34 and endothermic $286.27^{\circ} \mathrm{C}$. The loss in weight in the third step is gradual until it ends at $690^{\circ} \mathrm{C}$ with another $14.99 \%$, the compustion reaction completed at about $700^{\circ} \mathrm{C}$, the end of DTA line, the previous study nearly agreed with Abd-EL-Mounem, (1997). The DTA curve of both ureaformaldehyde resin hosting either two cations; $\mathrm{Ba}^{2+}$, $\mathrm{Ti}^{4+}$ or hosting four cation; $\mathrm{Ba}^{2+}$, $\mathrm{Ca}^{2+}, \mathrm{Ti}^{4+}, \mathrm{Zr}^{4+}$ are shown in Figs. (5-b,c) and Table (4). The effect of heat on the resin hosting cation nearly the as same as without cations. The peaks between $65^{\circ} \mathrm{C}$ to about 700 due to complete destruction of resin, table (4). A different pattern from the free resin spotted

in both patterns of resin hosting cations, is the presence of a small exothermic peak at $916.04^{\circ} \mathrm{C}$, it may be caused by crystallization of (BT).

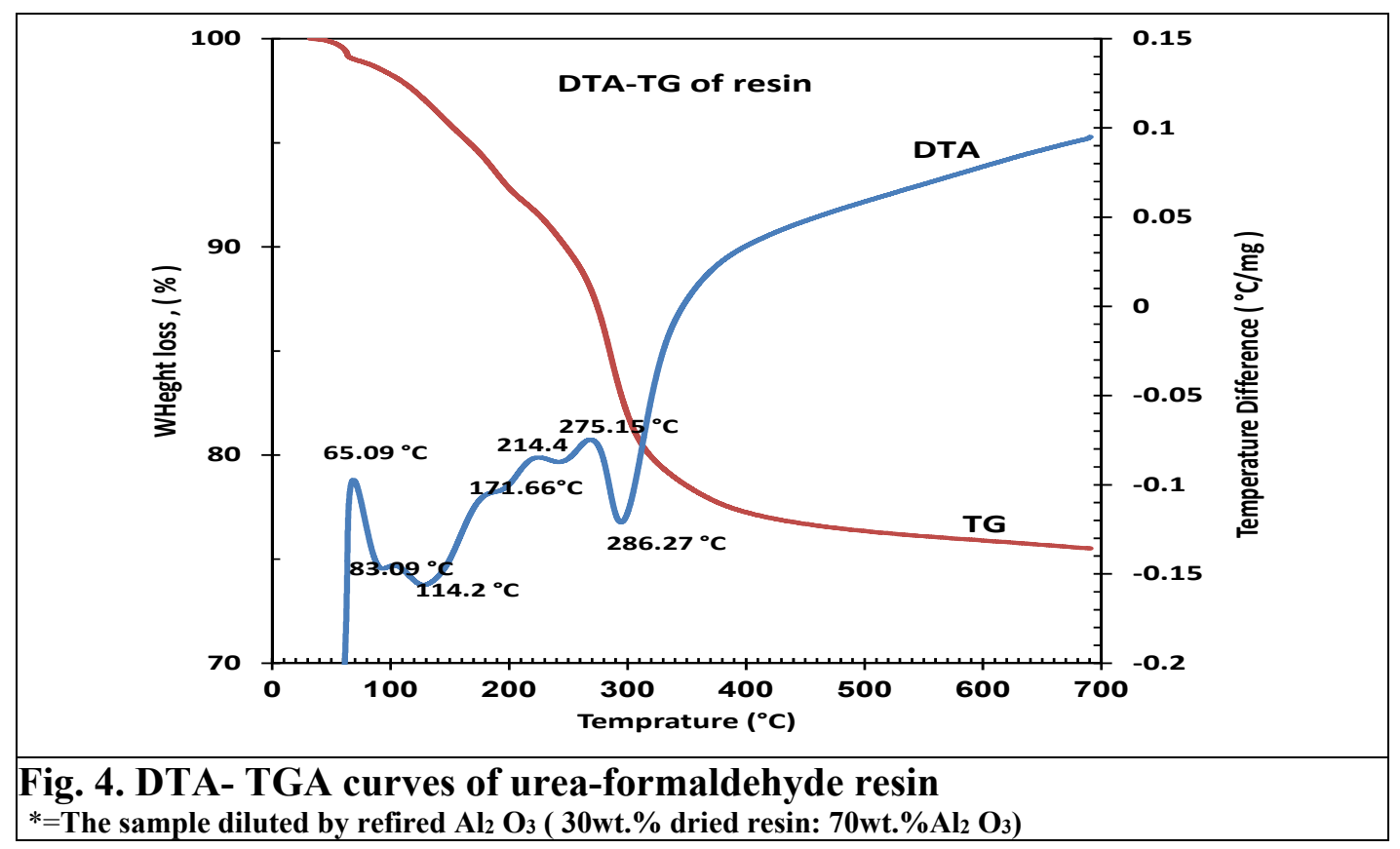




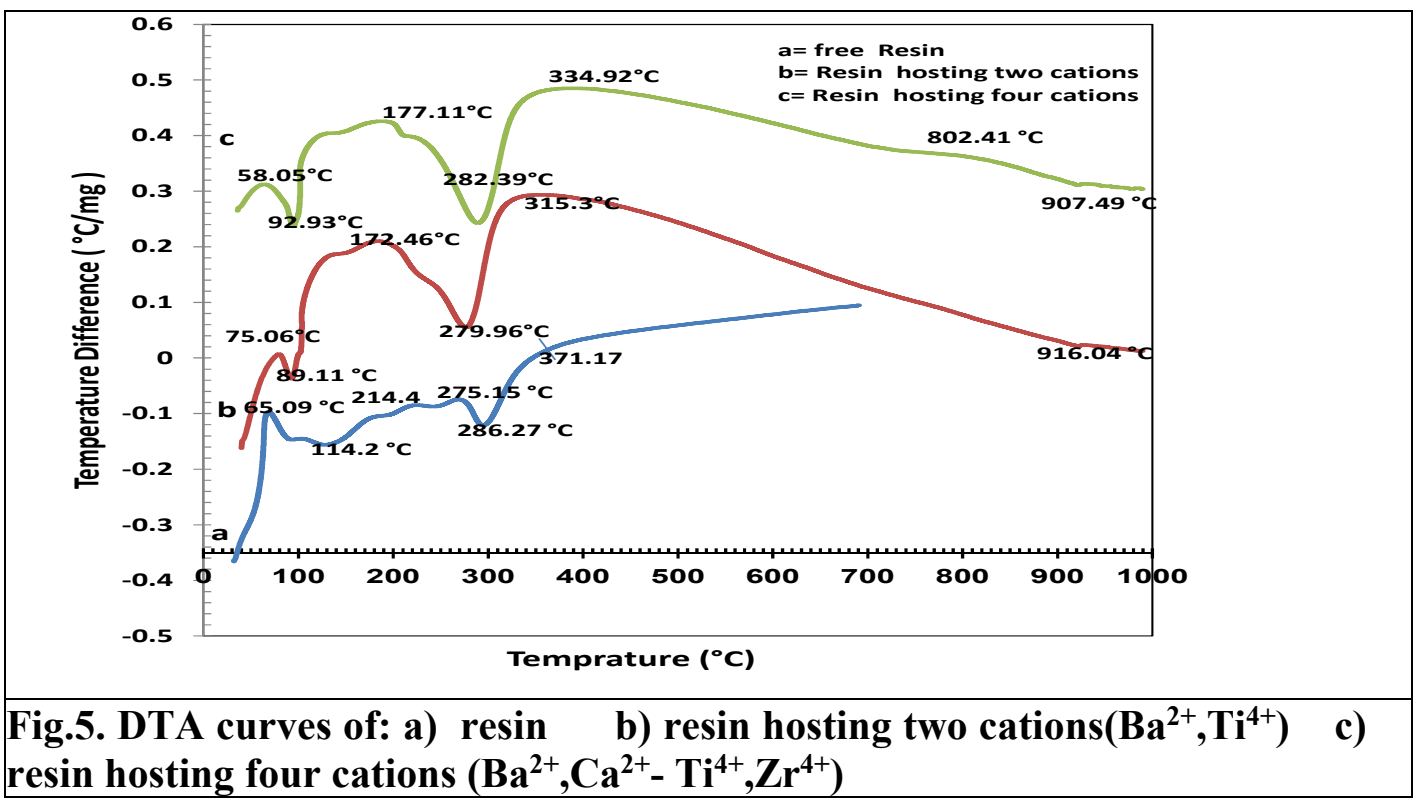

Table[3]: Temperatures of the main weight loss in Urea-formaldehyde resin detected in the TGA pattern

\begin{tabular}{|c|c|c|c|c|c|c|}
\hline \multirow{4}{*}{$\begin{array}{c}\text { Urea- } \\
\text { formaldehyde } \\
\text { resin }\end{array}$} & \multicolumn{6}{|c|}{ Main steps } \\
\cline { 2 - 7 } & $\begin{array}{c}\text { Temp. } \\
\text { range, }{ }^{\circ} \mathbf{C}\end{array}$ & $\begin{array}{c}\text { Wt. } \\
\text { loss, \% }\end{array}$ & $\begin{array}{c}\text { Temp. } \\
\text { range, } \\
{ }^{\circ} \mathbf{C}\end{array}$ & $\begin{array}{c}\text { Wt. } \\
\text { loss, } \\
\%\end{array}$ & $\begin{array}{c}\text { Temp. } \\
\text { range, } \\
{ }^{\circ} \mathbf{C}\end{array}$ & $\begin{array}{c}\text { Wt. loss, } \\
\%\end{array}$ \\
\cline { 2 - 7 } & $40-220$ & 31.75 & $220-325$ & 51.43 & $325-690$ & 14.99 \\
\hline
\end{tabular}

Table (4): Main DTA peaks detected in the patterns of the three polymers. free and hosting either two cations; $\mathrm{Ba}^{2+}, \mathrm{Ti}^{4+}$ or four cations; $\mathrm{Ba}^{2+}, \mathrm{Ca}^{2+}, \mathrm{Ti}^{4+}, \mathrm{Zr}^{4+}$

\begin{tabular}{|c|c|c|c|c|c|c|c|c|c|c|}
\hline \multirow[t]{2}{*}{ Material } & \multicolumn{5}{|c|}{$\begin{array}{c}\text { Endothermic peaks } \\
\text { temperature, }{ }^{\circ} \mathrm{C}\end{array}$} & \multicolumn{5}{|c|}{$\begin{array}{l}\text { Exothermic peaks } \\
\text { temperature, }{ }^{\circ} \mathrm{C} \text {. }\end{array}$} \\
\hline & $1^{\text {st }}$ & $2^{\text {nd }}$ & $3^{\text {rd }}$ & $4^{\text {th }}$ & $5^{\text {th }}$ & $1^{\text {st }}$ & $2^{\text {nd }}$ & $3^{\text {rd }}$ & $4^{\text {th }}$ & $5^{\text {th }}$ \\
\hline $\begin{array}{l}\text { Urea- } \\
\text { formaldehyde } \\
\text { resin }\end{array}$ & 83.09 & 114.2 & 191.34 & 235.34 & 286.27 & 214.4 & 275.15 & 371.17 & -- & -- \\
\hline $\begin{array}{l}\text { Urea- } \\
\text { formaldehyde } \\
\text { resin hosting, } \\
\mathrm{Ba}^{2+}, \mathrm{Ti}^{4+} \text { cations }\end{array}$ & 89.11 & 279.96 & 916.04 & -- & -- & 75.06 & 172.46 & 315.3 & -- & -- \\
\hline $\begin{array}{l}\text { Urea- } \\
\text { formaldehyde } \\
\text { resin hosting, } \\
\mathrm{Ba}^{2+}, \mathrm{Ca}^{2+}, \mathrm{Ti}^{4+}, \\
\mathrm{Zr}^{4+} \text { cations }\end{array}$ & 92.93 & 282.39 & 907.49 & -- & -- & 58.05 & 177.11 & 334.92 & 802.41 & -- \\
\hline
\end{tabular}


The X-ray diffraction (XRD) patterns of powder samples fired at $1000^{\circ} \mathrm{C}$ prepared using resin hosting both two as well as four cations were similar, as demonstrated in Table (5) and Fig. 6, Tetragonal Manardite phase $\left(\mathrm{Ba}_{1.15} \mathrm{Ti}_{8} \mathrm{O}_{16}\right)$, with crystallite size $16.5 \mathrm{~nm}$, was only detected in the undoped sample fired at $800^{\circ} \mathrm{C}$, beside remnants of the precursor barium chloride $\left(\mathrm{BaCl}_{2}\right)$. The unit cell dimensions recorded shows that grains will attain a platy shape as evident from the c/a ratio, Table 5. The estimated semiquantitave percent recorded was 15.7\%. Monoclinic ( $\left.\mathrm{BaTi}_{5} \mathrm{O}_{11}\right)$, with crystallite size $12.77,15.57 \& 21.4 \mathrm{~nm}$. at 800,1000 $\& 1100^{\circ} \mathrm{C}$, respectively, in the undoped powder and following the percent recorded; were 50.5 , 67.9 and $39 \%$, respectively. This indicates that, it gave path for another phase to manifest itself. Whereas, the recorded crystallite sizes for the doped powders were; $21.4 \& 19.03 \mathrm{~nm}$, at $1000 \&$ $1100^{\circ} \mathrm{C}$, respectively. It was detected as major phase reaching about $66 \%$ at $1000^{\circ} \mathrm{C}$, but reached $5 \%$ at $1100^{\circ} \mathrm{C}$, of the total crystalline phases. The expected shape for the phase is a prism as predicted from the lattice parameters determined. Monoclinic $\left(\mathrm{Ba}_{2} \mathrm{TiO}_{4}\right)$, with crystallite size $12.7 \mathrm{~nm}$ at $800^{\circ} \mathrm{C}$, that changed to the orthorhombic phase with size $15.57 \mathrm{~nm}$ at $1000^{\circ} \mathrm{C}$ and disappeared at $1100^{\circ} \mathrm{C}$. The recorded percent were 17.6 and $32.1 \%$, respectively. While the doped phase showed the orthorhombic phase at $1000^{\circ} \mathrm{C}$ with a slight coarser size of $17.3 \mathrm{~nm}$. It forms about $33.8 \%$, of the total crystalline phases. The change in the crystal form is accompanied by a change in the lattice parameters; axes and angles. Tetragonal $\left(\mathrm{BaTiO}_{3}\right)$, phase was not detected at $800^{\circ} \mathrm{C}$, but appeared at 1000 and $1100^{\circ} \mathrm{C}$; with crystallite size; 18.93 and $23.54 \mathrm{~nm}$. While the doped samples the calculated sizes were; 23.54 and $26.93 \mathrm{~nm}$, respectively. The semi-quantitave percents recorded were 30 and $20 \%$, respectively. Orthorhombic $\left(\mathrm{Ba}_{2} \mathrm{Ti}_{13} \mathrm{O}_{22}\right)$, was detected at $1100^{\circ} \mathrm{C}$, in both undoped and doped phases, with crystallite size; 24.47 and $22.54 \mathrm{~nm}$, while the recorded semi-quantitave percents were, 638.9 and $58.5 \%$, respectively. The phase equilibria in the $\mathrm{BaO}^{-\mathrm{TiO}_{2}}$ system show the presence of seven stable phases: $\mathrm{Ba}_{2} \mathrm{TiO}_{4}, \mathrm{BaTiO}_{3}, \mathrm{BaTi}_{3} \mathrm{O}_{5}, \mathrm{Ba}_{4} \mathrm{Ti}_{13} \mathrm{O}_{30}, \mathrm{BaTi}_{4} \mathrm{O}_{9}$, and $\mathrm{Ba}_{2} \mathrm{Ti}_{9} \mathrm{O}_{20}$, as reported by Lee et al., (2007) $\mathrm{BaTiO}_{3}$ is the most important of these compositions for its dielectric properties. It is directly formed from the respective oxides by solid state reaction at relatively high temperatures of $1350^{\circ} \mathrm{C}$. There are often problems obtaining a pure phase because of the intermediate formation of other compounds as $\mathrm{Ba}_{2} \mathrm{TiO}_{4}$

Table 5. The crystalline size, specific surface area, $X$-Ray density and lattice parameters of the resulted phases for powders prepared by using urea formaldehyde resin, calcined at different temperature, 800,1000 and $1100{ }^{\circ} \mathrm{C} / 3 \mathrm{~h}$ :

\begin{tabular}{|c|c|c|c|c|c|c|c|c|c|c|c|}
\hline \multicolumn{12}{|c|}{ BT powder prepared by using urea formaldehyde resin } \\
\hline $\begin{array}{l}\text { Calcination } \\
\text { temperature }\end{array}$ & $\begin{array}{l}\text { Phase } \\
\text { detected }\end{array}$ & $\begin{array}{l}\text { Semiquant- } \\
\text { itative, \% }\end{array}$ & \begin{tabular}{|l} 
X-Ray \\
Density \\
$\mathrm{g} / \mathrm{cm}^{3}$
\end{tabular} & $\begin{array}{l}\text { Space } \\
\text { group }\end{array}$ & $\begin{array}{c}\text { Volume } \\
\left(\AA^{3}\right)\end{array}$ & $\begin{array}{c}\mathrm{a} \\
(\AA)\end{array}$ & $\begin{array}{c}\mathrm{b} \\
(\AA)\end{array}$ & $\begin{array}{c}\mathrm{c} \\
(\AA)\end{array}$ & $\mathrm{c} / \mathrm{a}$ & $\begin{array}{c}\text { Crystalline } \\
\text { size }(n m)\end{array}$ & $\begin{array}{c}\text { Specific } \\
\text { surface } \\
\text { area } \\
\mathrm{m}^{2} / \mathrm{g}\end{array}$ \\
\hline \multirow{5}{*}{$800^{\circ} \mathrm{C} / 3 \mathrm{~h}$} & \begin{tabular}{|l|} 
Tetragonal- \\
(Manardite) \\
$\left(\mathrm{Ba}_{1.12} \mathrm{Ti}_{8} \mathrm{O}_{16}\right)$ \\
$(77-0883)$ \\
\end{tabular} & 15.7 & 4.38 & I4 (79) & 300.42 & 10.07 & 10.07 & 2.96 & 0.293 & 16.51 & 60.56 \\
\hline & $\begin{array}{l}\text { Monoclinic } \\
\left(\mathrm{Ba} \mathrm{Ti}_{5} \mathrm{O}_{11}\right) \\
(35-0805)\end{array}$ & 50.5 & 4.57 & $\begin{array}{c}\mathrm{P} 21 / \mathrm{n} \\
(14)\end{array}$ & 800.12 & 7.67 & 14.02 & 7.52 & 0.980 & 12.77 & 78.30 \\
\hline & \begin{tabular}{|l|} 
Monoclinic \\
$\left(\mathrm{Ba}_{2} \mathrm{Ti} \mathrm{O}_{4}\right)$ \\
$(35-0813)$
\end{tabular} & 17.6 & 4.57 & $\begin{array}{l}\mathrm{P} 21 / \mathrm{n} \\
(14)\end{array}$ & 494.24 & 10.54 & 7.67 & 6.11 & 0.579 & 14.27 & 70.07 \\
\hline & $\begin{array}{l}\mathrm{Ba} \mathrm{Cl} 2 \\
01-0948\end{array}$ & 16.2 & - & - & - & - & - & - & - & - & - \\
\hline & $\begin{array}{l}\text { Monoclinic } \\
\left(\mathrm{Ba} \mathrm{Ti}_{5} \mathrm{O}_{11}\right) \\
(74-0538)\end{array}$ & 67.9 & 4.589 & $\begin{array}{l}\mathrm{P} 21 / \mathrm{n} \\
(14)\end{array}$ & 800.12 & 7.67 & 14.02 & 7.52 & 0.980 & 15.57 & 64.22 \\
\hline
\end{tabular}


Journal of Environmental Studies and Researches (2020)

\begin{tabular}{|c|c|c|c|c|c|c|c|c|c|c|c|}
\hline $1000^{\circ} \mathrm{C} / 3 \mathrm{~h}$ & $\begin{array}{l}\text { Orthorhombic } \\
\left(\mathrm{Ba}_{2} \mathrm{Ti} \mathrm{O}_{4}\right) \\
(38-1481)\end{array}$ & 32.1 & 5.208 & $\begin{array}{c}\text { Pnam } / n \\
(62)\end{array}$ & 492.97 & 7.65 & 10.55 & 6.10 & 0.797 & 17.12 & 58.41 \\
\hline \multirow{3}{*}{$1100^{\circ} \mathrm{C} / 3 \mathrm{~h}$} & $\begin{array}{l}\text { Tetragonal } \\
\left(\mathrm{BaTiO}_{3}\right)- \\
(80-6372)\end{array}$ & 21.2 & 5.05 & $\begin{array}{c}\text { P4mm } \\
\text { (99) }\end{array}$ & 76.55 & 4.31 & 4.31 & 4.10 & 0.951 & 26.56 & 46.38 \\
\hline & $\begin{array}{l}\text { Orthorhombic } \\
\left(\mathrm{Ba}_{2} \mathrm{Ti}_{13} \mathrm{O}_{22}\right)- \\
(82-1430)\end{array}$ & 38.9 & 5.02 & $\begin{array}{c}\text { Cmca } \\
(64)\end{array}$ & 1652.87 & 11.65 & 14.10 & 10.05 & 0.862 & 24.47 & 40.86 \\
\hline & $\begin{array}{l}\text { Monoclinic } \\
\left(\mathrm{Ba} \mathrm{Ti5}_{5} \mathrm{O}_{11}\right) \\
(74-0538)\end{array}$ & 39.0 & 4.589 & $\begin{array}{c}\mathrm{P} 21 / \mathrm{n} \\
(14)\end{array}$ & 802.64 & 7.66 & 14.04 & 7.53 & 0.983 & 21.41 & 64.72 \\
\hline \multicolumn{12}{|c|}{ BCTZ- prepared by using urea formaldehyde resin } \\
\hline $\begin{array}{l}\text { Calcination } \\
\text { temperature }\end{array}$ & system & \begin{tabular}{|c|} 
Semiquant- \\
titative \\
$\%$
\end{tabular} & $\begin{array}{c}\text { X-Ray } \\
\text { Density } \\
\mathrm{g} / \mathrm{cm}^{3}\end{array}$ & $\begin{array}{l}\text { Space } \\
\text { group }\end{array}$ & $\begin{array}{l}\text { Volume } \\
\left(\AA^{3}\right)\end{array}$ & $\mathrm{a}(\AA)$ & $\mathrm{b}(\AA)$ & $\mathrm{c}(\AA)$ & $\mathrm{c} / \mathrm{a}$ & $\begin{array}{l}\text { Crystalline } \\
\text { Size }(\mathrm{nm})\end{array}$ & $\begin{array}{c}\text { Specific } \\
\text { surface } \\
\text { area } \\
\mathrm{m}^{2} / \mathrm{g}\end{array}$ \\
\hline \multirow[t]{2}{*}{$1000^{\circ} \mathrm{C} / 3 \mathrm{~h}$} & $\begin{array}{c}\text { Monoclinic } \\
\left(\mathrm{Ba} \mathrm{Ti}_{5} \mathrm{O}_{11}\right) \\
(74-0538)\end{array}$ & 66.2 & 4.589 & $\begin{array}{c}\mathrm{P} 21 / \mathrm{n} \\
(14)\end{array}$ & 800.12 & 7.67 & 14.02 & 7.52 & 0.980 & 21.41 & 46.72 \\
\hline & $\begin{array}{c}\text { Orthorhombic } \\
\left(\mathrm{Ba}_{2} \mathrm{Ti} \mathrm{O}_{4}\right) \\
(38-1481)\end{array}$ & 33.8 & 5.208 & $\begin{array}{c}\text { Pnam/n } \\
(62)\end{array}$ & 492.97 & 7.65 & 10.55 & 6.10 & 0.797 & 17.3 & 57.80 \\
\hline \multirow[t]{3}{*}{$1100^{\circ} \mathrm{C} / 3 \mathrm{~h}$} & $\begin{array}{l}\text { Tetragonal } \\
\left(\mathrm{BaTiO}_{3}\right)- \\
(80-6372)\end{array}$ & 36.5 & 5.05 & $\begin{array}{c}\text { P4mm } \\
(99)\end{array}$ & 76.55 & 4.31 & 4.31 & 4.10 & 0.951 & 26.93 & 37.13 \\
\hline & $\begin{array}{c}\text { Orthorhombic } \\
\left(\mathrm{Ba}_{2} \mathrm{Ti}_{13} \mathrm{O}_{22}\right)- \\
(82-1430) \\
\end{array}$ & 58.5 & 5.02 & $\begin{array}{c}\text { Cmca } \\
(64) \\
\end{array}$ & 1652.87 & 11.65 & 14.10 & 10.05 & 0.862 & 22.54 & 44.36 \\
\hline & $\begin{array}{c}\text { Monoclinic } \\
\left(\mathrm{Ba} \mathrm{Ti5}_{11} \mathrm{O}_{11}\right. \\
(74-0538)\end{array}$ & 5.0 & 4.589 & $\begin{array}{c}\mathrm{P} 21 / \mathrm{n} \\
(14)\end{array}$ & 802.64 & 7.66 & 14.04 & 7.53 & 0.983 & 19.03 & 52.54 \\
\hline
\end{tabular}

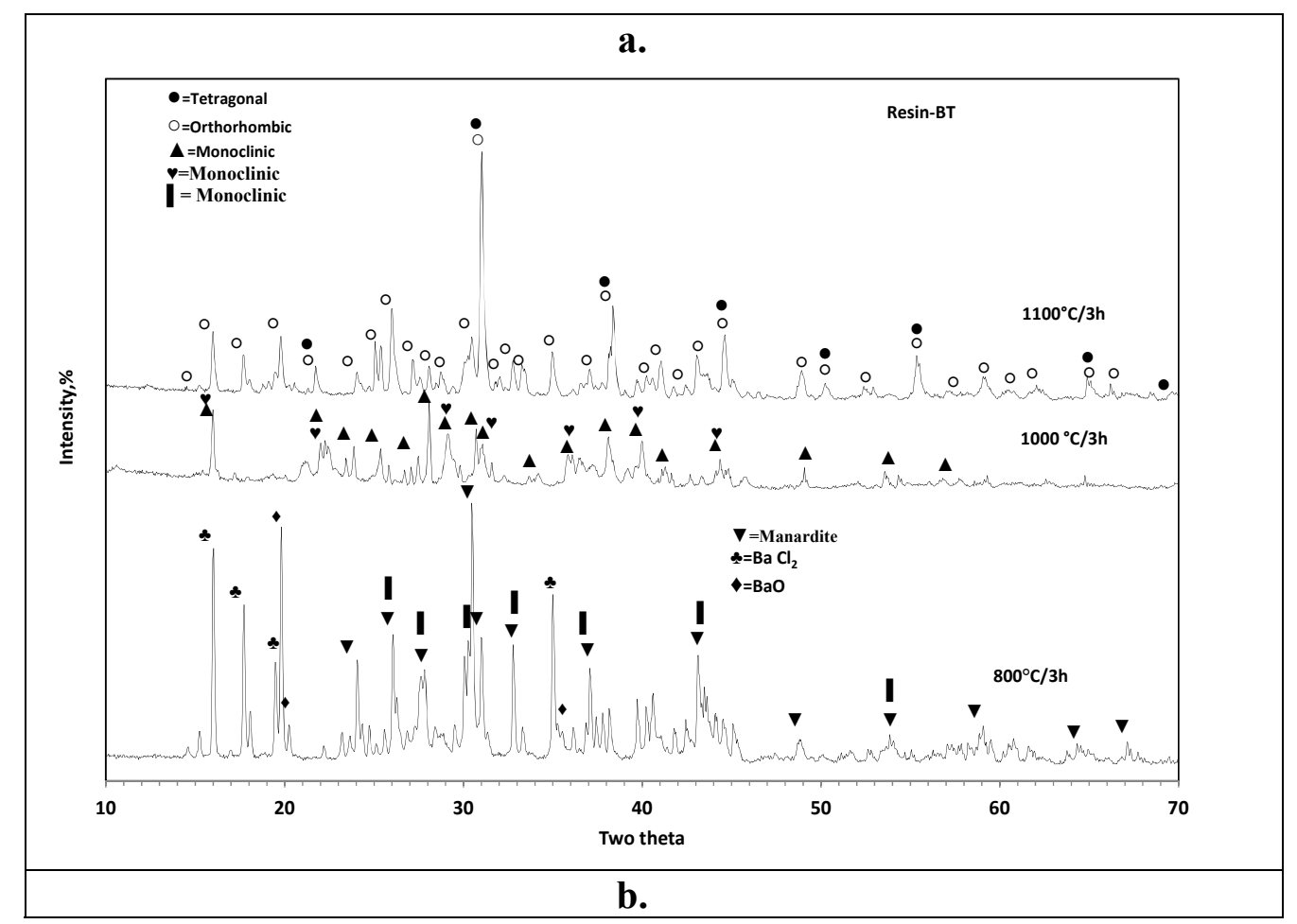




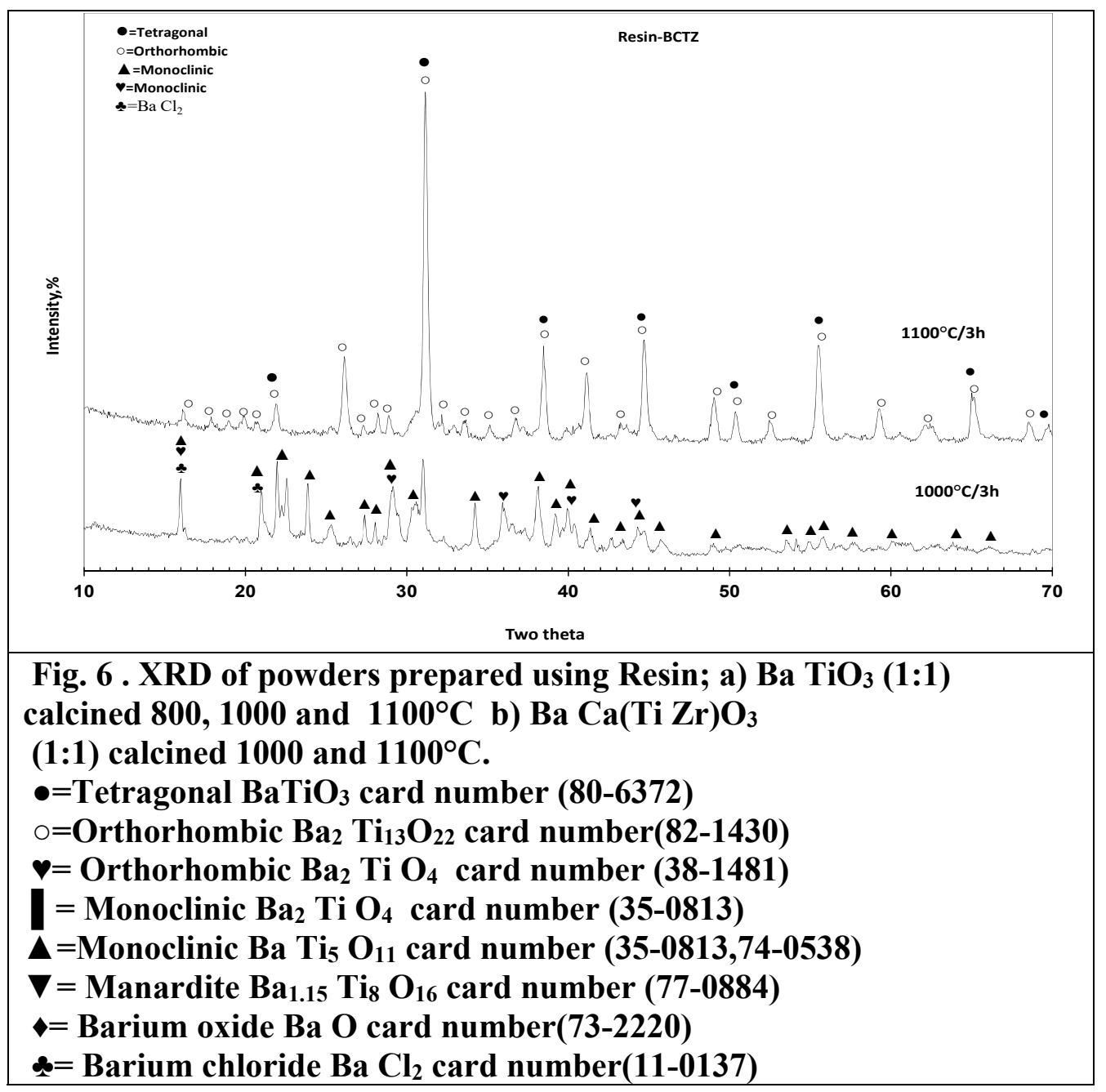

still the chemical synthesis route, as sol-gel process, results in the presence of such phases as: $\mathrm{Ba}_{2} \mathrm{TiO}_{4}, \mathrm{BaTi}_{2} \mathrm{O}_{5}$ and $\mathrm{BaTi}_{4} \mathrm{O}_{9}$. It is governed by the availability of the respective cations to participate in the reaction. The appearance of the other titanate as major phases; $\mathrm{Ba}_{2} \mathrm{TiO}_{4}, \mathrm{BaTi}_{5} \mathrm{O}_{11}$ as well as $\mathrm{Ba}_{4} \mathrm{Ti}_{13} \mathrm{O}_{30}$, indicates that the needed ratios for their formation of the reactants were available. This is expected, as a conspicuous portion of the $\mathrm{BaCl}_{2}$ did not participate in the polymer structure and left it enriched in $\mathrm{TiO}_{2}$, giving path to their

$\mathrm{BaCO}_{3}$ and $\mathrm{TiO}_{2}$ and firing at temperatures between 700 and $1150^{\circ} \mathrm{C}$. According to $\mathbf{H s u}$ et al., (2013), Monoclinic $\mathrm{BaTi}_{5} \mathrm{O}_{11}$ readily forms between 700 to $800^{\circ} \mathrm{C}$, and sintered at $1100^{\circ} \mathrm{C} / 4 \mathrm{~h}$. While, $\mathrm{Ba}_{4} \mathrm{Ti}_{13} \mathrm{O}_{30}$ as a single phase was difficult to prepare. It was obtained as film through CVD by laser Guo et al., (2012) and as nano crystals by a hydrothermal method utilizing barium acetate Li et al., (2019). 

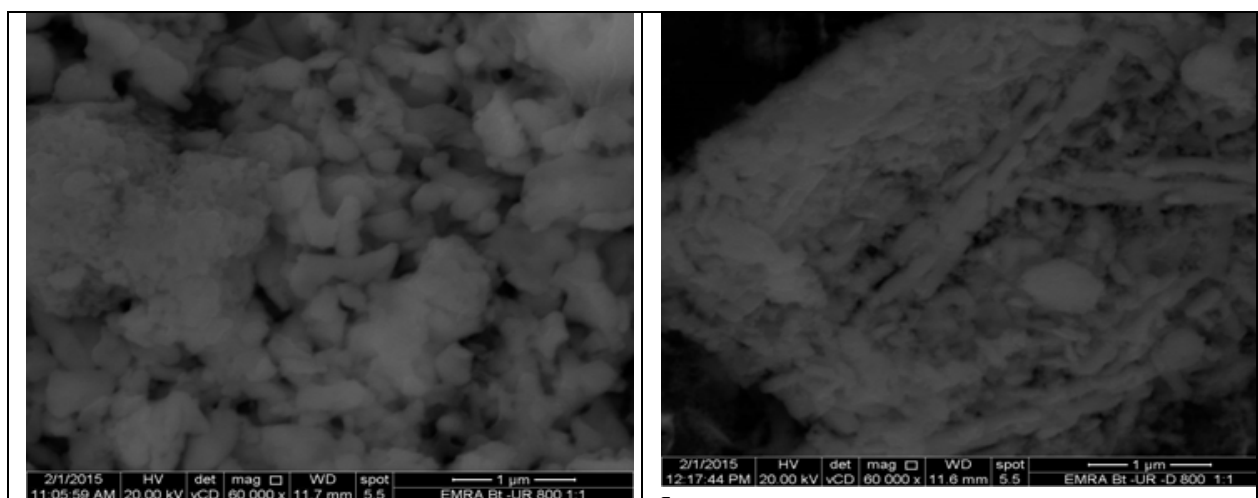

a.

b.

Fig. 7. SEM of powders a) $\mathrm{BaTiO}_{3}(1: 1)$ powder fired at $800{ }^{\circ} \mathrm{C} /$

3h. b) Ba $\mathrm{Ca}(\mathrm{Ti} \mathrm{Zr}) \mathrm{O}_{3}(1: 1)$ powder fired at $800{ }^{\circ} \mathrm{C} / 3 \mathrm{~h}$.

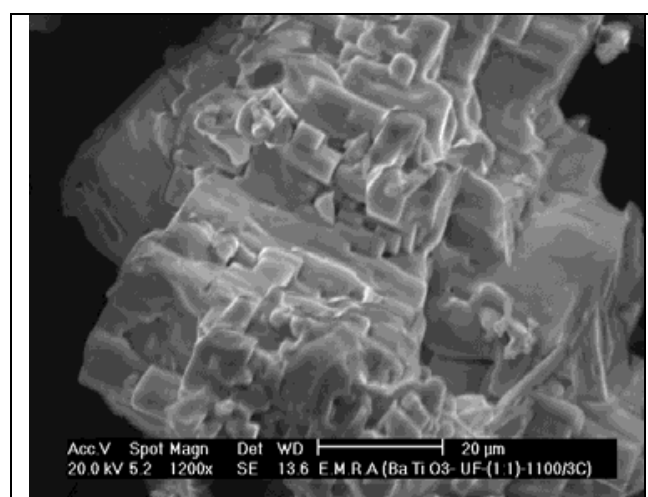

a.

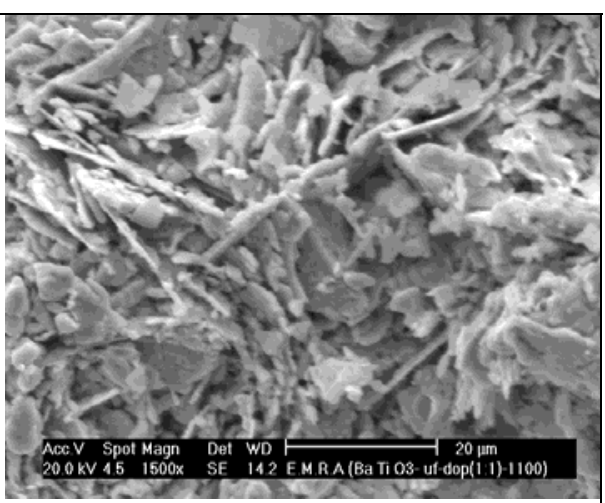

b.

Fig. 8. SEM of powders;a) $\mathrm{BaTiO}_{3}(1: 1)$ powder fired at 1100 ${ }^{\circ} \mathrm{C} / 3 \mathrm{~h}$. b) $\mathrm{Ba} \mathrm{Ca}(\mathrm{Ti} \mathrm{Zr}) \mathrm{O}_{3}(1: 1)$ powder fired at $1100{ }^{\circ} \mathrm{C} / 3 \mathrm{~h}$.

The SEM micrographs of the powder calcined at 800 as well as $1100{ }^{\circ} \mathrm{C}$ showing morphology and particle size of products are illustrated in Fig. 7 and 8, respectively. All of these were well crystallized and crystallite growth occurs at this temperature showing the former structure of the resin net work lace like very uniform distribution of pores between the particles, shows the structure of the resin with pores very uniform in size and its shape nearly spherical, resulting from the volatilization of the organic matter of the resin. The oxide grains are fused together having flaky shape agglomeration of particle. As the same as for the received powder at $1100^{\circ} \mathrm{C}$, the particles nearly discrete. The crystal size, grin growth increase with increasing calcination temperature between $800-1100^{\circ} \mathrm{C}$. This result agreed with another authors [Bongkarn et al., 2008 \& Ghayour and Abdellahi, 2016], The obtained SEM micrographs show the flaky shape phenomena of the particle with bimodal distribution. Micrograph analyses demonstrate that with increasing the temperature, larger grains are formed either from single grains or as a result of the agglomeration of smaller grains [Mesquita et al., 2012]. used for Doping by $\mathrm{Ca}^{2+}, \mathrm{Zr}^{4+}$ on $\mathrm{Ba} \mathrm{TiO}_{3}$ enhance the microstructure, grain growth of the prepared powder [Zhang et al., 2009 and Hsieh et al., 2012].

\section{CONCLUSION}

Pure perovskite (Tetragonal-orthorhombic-monoclinic) barium polytitanate (BT) and (Tetragonal-orthorhombic-monoclinic) (BCTZ) powder was obtained at a calcination temperature of $1100^{\circ} \mathrm{C} / 3 \mathrm{~h}$, utilizing sol gel polymeric method using urea formaldehyde resin. 
The starting material as barium chloride has an effect of on the resulted microstructure. The urea formaldehyde resin affect the microstructure of the prepared powder.

\section{REFERENCES}

Abd-EL-Mounem A.,(1997), Preparation of aluminum titanate by non conventional routes and study the effect of some additives on its stability, Ph.D. thesis, faculty of science - department of chemistry, cairo university.

Akbarzadeh N. T. and Amiri L.O., 2015. Synthesis and Characterization of Barium-Vanadium Oxide Nanocomposite Using a Facile thermolysis., Approach., Orient. J. Chem., Vol. 31(4), 2247-2251.

Bazeera A.Z. and Amrin M. I., 2017. Synthesis and Characterization of Barium Oxide Nanoparticles: IOSR Journal of Applied Physics (IOSR-JAP) -ISSN: 2278-4861, PP 76-80.

Beck H.P., Eiser W., Haberkorn R., 2001, Pitfalls in the synthesis of nanoscaled peroveskite type compounds Part 1: influence of different sol-gel preparation methods and characterizations of nanoscaled $\mathrm{Ba} \mathrm{TiO}_{3}$, J. Eur. Cer. Soc., vol. 21, pp. 687-693.

Bongkarn T., Phungjitt N., Vittayakorn N., 2008. Phase Formation and Microstructure of Ceramics Prepared via Solid State Reaction Method., Journal of Microscopy Society of Thailand 2008, 22: 30-33.

Cheung M.C., Chan H.L.V., Zhou Q.F., Choy C.L., 1999, characterization of barium titanate ceramic/ceramic nanocomposite films prepared by sol-gel process, NanoStructured Materials, vol. 11 , pp. 837-844.

Ertuğ,2013. The Overview of The Electrical Properties of Barium Titanate. American Journal of Engineering Research (AJER) e-ISSN : 2320-0847 p-ISSN : 2320-0936 Volume02, Issue-08, pp-01- 07.

Ghayour H., Abdellahi M..,2016. A brief review of the effect of grain size variation on the electrical properties of $\mathrm{BaTiO}_{3}$-based ceramics., Powder Technology 292, 84-93.

Guo D. , Ito A. , Goto T. , Tu R. , Wang C. , Shen Q. , Zhang L., Dielectric properties of $\mathrm{Ba}_{4} \mathrm{Ti}_{13} \mathrm{O}_{30}$ film prepared by laser chemical vapor deposition., J Mater Sci (2012) 47:15591561.

Harizanov, O.A., 1998, Sol-gel $\mathrm{BaTiO}_{3}$ from a peptized solution, Materials letters, 34(3-6), pp. 232-236

Harizanov,O.A.,1998,Formation and crystallization of an acetate-acetylacetonate derived sol-gel $\mathrm{BaTiO}_{3}$, Materials letters,34(3-6),pp.345-350.

Harizanov O., Harizanova A., Ivanova T., (2004), Formation and Characterization of sol-gel barium titanate, Mat. Sci. Eng. B106,191-195.

Herbert, J.M., 1985. Ceramic Dielectrics and Capacitors, Gordon and Breach Science Publishers, , pp. $128-187$.

Hsieh T.H., Yen S.C., Ray D.T.,(2012), A study on the synthesis of (Ba,Ca)(Ti,Zr)O 3 nano powders using Pechini polymeric precursor method., Ceramics International 38, 755-759.

Hsu C.H., Chen W.S., Tung H.H., Yang P.C., and Lin J.S.,2013., Dielectric Properties of $\mathrm{BaTi}_{5} \mathrm{O}_{11}$ Ceramics at Microwave Frequencies., Advanced Materials Research., ISSN: 16628985, Vol. 677, pp,153-156.

Ibrahim, D.M.; Toman do, G. and Ghoneim, N.M. 1991.Urea-Formaldehyde as a Precursor for the Preparation of Zirconia by Sol-Gel Process. Mat. Sci. Monograph (Ceram. Today Tomorrow's Pt. B.), 66 B, 881-87.

Ibrahim D.M., Mostafa A.A., Khalil T., (1999). Preparation of tialite (aluminium titanate) via the urea formaldehyde polymeric route., Ceramics International 25 (1999) 697-704.

Jiang B., Peng J.L., Bursill L.A., Ren T.L., Zhang P.L., Zhong W.L., (2000),Defect structure and

physical propertes of barium titanate ultra-fineparticles, Physica B291 203-212. 
Jiang B., Peng J.L., Bursill L.A., Ren T.L., Zhang P.L., Zhong W.L. 2000, Physica, vol. B 291, pp. 203-212.

Lee B. and Zhang J., 2001, Preparation, structure evolution and dielectric properties of $\mathrm{Ba}^{\mathrm{TiO}_{3}}$ Thin films and powders by an aquas sol gel process., Thin Solid Films, vol. 388, pp. 107-113.

Lee S., Randall, C. A.and Liu, Z-K., 2007. Modified Phase Diagram for the Barium OxideTitanium Dioxide System for the Ferroelectric Barium Titanate., J. Am. Ceram. Soc., 90 [8] 2589-2594.

Li S., Li X., Zou K., Huang Z., Zhang L., Guo D., Ju Y.,2019., Ba4Ti13 $\mathrm{O}_{30}$ nanocrystals prepared by hydrothermal method., Int J Ceramic Eng Sci.;00:1-4.

Mesquita A., Bernardi M.B., Godart C., Pizani P.S., Michalowicz A., Mastelaro V., (2012). Grain size effect on the structural and dielectric properties of $\mathrm{Pb}_{0.85} \mathrm{La}_{0.15} \mathrm{TiO}_{3}$ ferroelectric ceramic compound, Ceram. Int. 38 5879-5887.

Pontes F. M., Lea S. H., Leite E. R., Longo E., Pizani P. S., Chiquito A. J., Varela J. A., (2004), Investigation of phase transition in ferroelectric $\mathrm{Pb}_{0.70} \mathrm{Sr}_{0.30} \mathrm{TiO}_{3}$ thin films, J. Appl. Phys. 96, 1192.

Yi, W.C., Kalkur T.S., 2001. Dielectric properties of Mg-doped $\mathrm{BaCaZrO}_{3}$ thin films fabricated by metalorganic decomposition method, Appl. Phys. Lett.78 (22) 3517-3519.

Zhang S.W., Zhang H. , Zhang B.P., Zhao G., 2009. Dielectric and piezoelectric properties of $\left(\mathrm{Ba}_{0.95} \mathrm{Ca}_{0.05}\right)\left(\mathrm{Ti}_{0.88} \mathrm{Zr}_{0.12}\right) \mathrm{O}_{3}$ ceramics sintered in a protective atmosphere., Journal of the European Ceramic Society 29,3235-3242. 